\title{
PENGARUH E-SERVICE QUALITY DAN BRAND IMAGE TERHADAP CONTINUANCE USAGE INTENTION PLATFORM DANA DOMPET DIGITAL OLEH GENERASI Y DAN Z
}

\author{
Ayuni ${ }^{1}$ \\ Siti Nabillah Suci Amanda² \\ Abdul Yusuf ${ }^{3}$ \\ 1,2,3Universitas Singaperbangsa Karawang \\ "Corresponding Author: 1910631020075@student.unsika.ac.id
}

\begin{abstract}
The purpose of this study is to test whether E-Service Quality and Brand Image affect the Continuance Usage Intention of the DANA Dompet Digital Indonesia Platform. This study uses quantitative research, the population of this study is the users of DANA Dompet Digital Indonesia. The research data was collected through a questionnaire with a sample of 100 respondents consist of 73 women and 27 men respondents using non-probability sampling (purposive sampling) is a sampling technique based on certain considerations that are considered to represent, a population with the categories of generations $Y$ and $Z$ in the age range of 17-40 years and majority respondents are university students. Data were analyzed using SPSS 25 and SmartPLS 3.0. The results showed that E-Service Quality had a significant effect on the Continuance Usage Intention of the DANA Dompet Digital platform and Brand Image had a significant effect on the Continuance Usage Intention of DANA Dompet Digital.
\end{abstract}

Keywords: E-Service Quality, Brand Image, Continuance Usage Intention, DANA

\section{PENDAHULUAN}

Internet merupakan sebuah hasil dari berkembangnya teknologi pada era modern seperti sekarang ini. Dengan pertumbuhannya yang sangat cepat, internet dapat mempermudah kebutuhan sehari-hari seperti keuangan, bisnis, dan pendidikan. Di Indonesia sendiri, hampir setengah populasinya adalah pengguna internet. Kementerian 
Komunikasi dan Informatika RI (Kemenkominfo) memaparkan bahwa Indonesia menjadi negara dengan pengguna internet terbanyak dan menduduki peringkat ke-4 di dunia. Asosiasi Penyelenggara Jasa Internet Indonesia (APJII), melakukan survey untuk mengetahui berapa jumlah penetrasi dan pengguna internet di Indonesia. Hasilnya, pengguna internet di tahun 2019-2020 mencapai 196,7 juta pengguna dengan persentase penetrasi pengguna internet sebesar $73,7 \%$ dari total populasi di Indonesia sebanyak 266,9 juta pengguna. Jumlah penetrasi pengguna internet tersebut meningkat sebesar $8,9 \%$ atau sekitar 25,5 juta pengguna dari survey yang dilakukan sebelumnya pada tahun 2018.

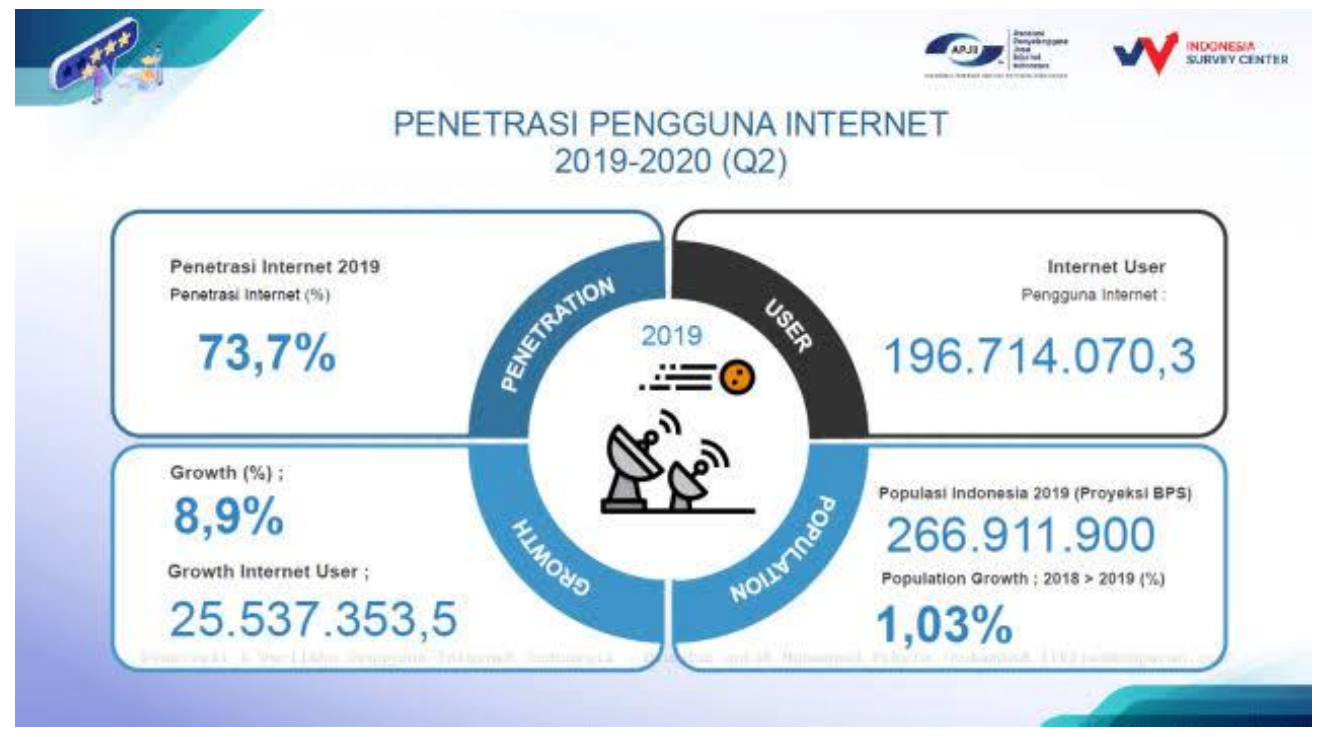

\section{Gambar 1. Penetrasi Pengguna Internet Tahun 2019-2020}

Sumber: apjii.or.id

Berdasarkan data di atas, dapat kita lihat bahwa jumlah pengguna internet di Indonesia sangatlah besar. Hal ini dipicu oleh kepuasan pengguna dalam mengakses internet yang cepat dan mudah. Internet memberikan dampak positif pada kebutuhan sehari-hari salah satunya adalah sektor bisnis. Banyak pelaku usaha di Indonesia yang melakukan suatu inovasi untuk menciptakan produk layanan berbasis financial technology yang bertujuan memudahkan pengguna dalam melakukan berbagai macam transaksi secara online.

Financial Technology atau fintech merupakan hasil gabungan antara jasa keuangan dengan teknologi yang akhirnya mengubah model bisnis dari konvensional menjadi moderat. Sebelum era digitalisasi berkembang, seluruh aktivitas pembayaran masih dilakukan dengan menggunakan uang sebagai alat tukar. Semakin berkembangnya zaman dengan munculnya digitalisasi, telah mengubah sistem pembayaran yang sebelumnya menggunakan sistem pembayaran tunai menjadi sistem cashless atau pembayaran non-tunai. Sistem cashless ini tidak terlepas dari eksistensi 
platform digital wallet sebagai penyedia layanan yang dapat menyimpan seluruh aktivitas transaksi keuangan pengguna.

Digital wallet merupakan salah satu financial technology (fintech) yang pada dasarnya memiliki tujuan untuk mengurangi penggunaan uang tunai dengan menyediakan suatu platform pembayaran yang dikombinasikan dengan mobile technology untuk dapat menciptakan kemudahan dalam bertransaksi. Untuk pembayaran produk/layanan, masing-masing layanan digital wallet memiliki cara pembayaran yang berbeda-beda bergantung pada aplikasinya masing-masing (Putra, 2021). Dewasa ini, digital wallet menjadi salah satu produk FinTech yang paling sering digunakan oleh banyak konsumen terutama generasi $Y$ dan $Z$. Alasan mereka memilih menggunakan digital wallet pun beragam, yakni seperti yang tercantum pada grafik di bawah ini:

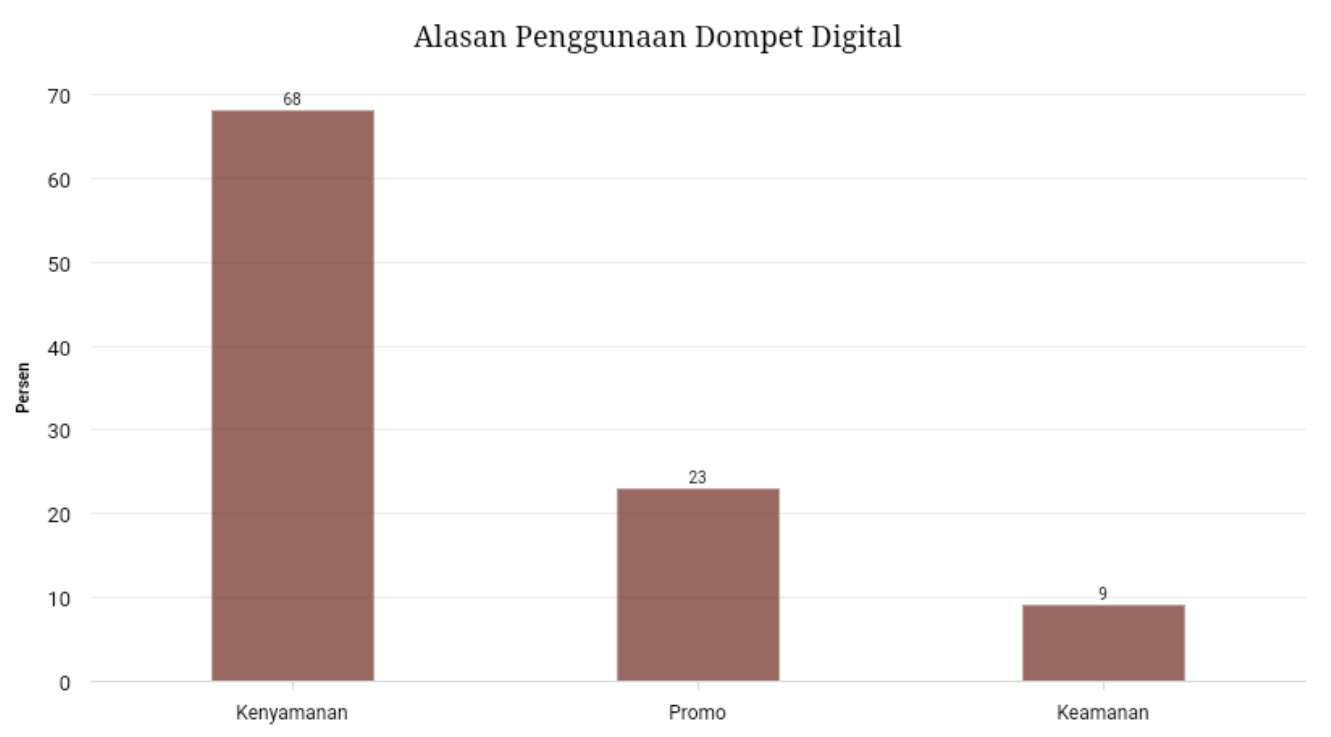

Dkatadata

\section{Gambar 2. Alasan Penggunaan Dompet Digital}

Sumber: databoks.katadata.co.id

Kenyamanan menjadi alasan paling utama bagi banyak konsumen untuk menggunakan digital wallet dengan persentase sebesar $68 \%$. Hal ini dikarenakan sistem penggunaan digital wallet yang dianggap sangat praktis, konsumen tidak perlu lagi membawa banyak uang tunai dan kartu debit/kredit karena semua transaksi dapat dilakukan hanya lewat smartphone. Promo menjadi alasan kedua penggunaan digital wallet dengan persentase sebesar $23 \%$, konsumen pastinya sangat tergiur dengan penawaran-penawaran yang bersifat promo karena dianggap menguntungkan bagi mereka. Alasan ketiga yakni keamanan dengan persentase sebesar $9 \%$. Untuk 
masyarakat Indonesia sendiri terdapat 5 jenis digital wallet yang paling sering mereka gunakan untuk bertransaksi yaitu DANA, OVO, ShopeePay, GoPay, dan LinkAja.

Pada penelitian ini, platform digital wallet yang akan kami teliti adalah DANA Dompet Digital Indonesia. DANA didirikan pada 5 Desember 2018 oleh Eliza Sariaatmadja dan memiliki kerjasama khusus dengan bank-bank nasional, seperti Bank Mandiri, BCA, BRI, CIMB NIAGA, BNI, Panin Bank, Bank Permata, BTN dan Bank Sinar Mas (Wikipedia, 2021). Berdasarkan survey yang dilakukan oleh YouGov Indonesia, disebutkan bahwa pengguna DANA meningkat jumlahnya sebesar $40 \%$ di kuartal II tahun 2021. Pertumbuhan pengguna DANA yang tinggi, dipicu oleh bertambahnya pengguna dikalangan generasi $Y$ dan $Z$ (sekitar 18-35 tahun). DANA juga merilis data pertumbuhan pengguna dari 50 juta pada akhir tahun 2020 menjadi 80 juta pada pertengahan Agustus 2021.

Persepsi pengguna terhadap DANA juga meningkat. Alasan pengguna smartphone memilih untuk menggunakan DANA karena kemudahan yang disajikan pada fitur-fitur di dalamnya, keamanan yang sudah terjamin pada sistemnya serta bebas biaya administrasi. Dengan kenyamanan yang didapatkan pengguna serta aplikasi yang userfriendly, memberikan kepuasan tersendiri bagi pengguna khususnya generasi $\mathrm{Y}$ dan $\mathrm{Z}$ ketika menggunakan DANA. Hal ini membawa dampak positif yaitu niat penggunaan keberlanjutan dari pengguna untuk menggunakan DANA sebagai sarana transaksi secara online.

Niat penggunaan berkelanjutan FinTech hanya terfokus pada FinTech pembayaran seluler yang termasuk dalam subsegmen metode pembayaran alternatif. Istilah "pembayaran seluler" didefinisikan sebagai berbagai fungsi yang diadakan melalui teknologi ponsel untuk melakukan pembayaran, transfer bank, eWallet, dan transfer peerto-peer (transfer uang antara dua individu secara real-time). Dibandingkan dengan penyedia layanan keuangan tradisional, kenyamanan melalui FinTech pembayaran seluler adalah alasan yang dapat diterima untuk menetapkan manfaat yang dirasakan dari niat menggunakan FinTech pembayaran seluler. Manfaat ekonomi, transaksi tanpa batas, dan kenyamanan mungkin memengaruhi keseluruhan manfaat yang dirasakan dari FinTech pembayaran seluler, sehingga memengaruhi niat kelanjutannya (Putritama, 2019).

Untuk dapat menggugah keinginan pengguna memiliki niat untuk menggunakan dompet digital secara berkelanjutan, cara yang dapat dilakukan adalah dengan memberikan pelayanan elektronik atau E-Service Quality kepada pengguna dan melihat bagaimana Brand Image yang dimiliki oleh DANA. Dua hal tersebut menjadi bagian penting karena E-Service Quality dan Brand Image yang baik dari suatu produk akan meningkatkan kepercayaan dari pengguna untuk menggunakannya secara terus menerus. Oleh sebab itu, dilakukannya penelitian ini bertujuan untuk mengetahui apakah E-Service Quality berpengaruh positif atau negatif terhadap continuance usage intention 
serta mengetahui apakah Brand Image berpengaruh positif atau negatif terhadap Continuance Usage Intention pada aplikasi DANA oleh generasi Y dan Z.

\section{TELAAH PUSTAKA}

\section{Niat Penggunaan Berkelanjutan (Continuance Usage Intention)}

Niat penggunaan berkelanjutan mengacu pada pelanggan akan melakukan pembelian atau penggunaan terhadap suatu produk secara berkelanjutan. Niat penggunaan berkelanjutan secara umum adalah kesetiaan seseorang atas suatu produk tertentu, baik barang maupun jasa. Dengan kata lain, niat penggunaan berkelanjutan adalah suatu ukuran dimana seberapa sering konsumen menggunakan merek tertentu (Liempepas \& Sihombing, 2019). Niat atau loyalitas penggunaan berkelanjutan mengungkapkan perilaku terbuka yang dimaksudkan terhadap produk/layanan atau atributnya. Konsumen yang merasa puas dengan produk yang dibeli akan memiliki peluang yang lebih tinggi bagi konsumen tersebut untuk membeli kembali produk atau jasa yang sama atau produk turunan lainnya di masa yang akan datang. Ketika konsumen menggunakan atau mengkonsumsi produk atau jasa yang dibeli, tingkat harapan konsumen akan menentukan tingkat kepuasan dan niat pembelian ulang di masa yang akan datang. Dimensi dari Continuance Usage Intention terbagi menjadi sebagai berikut:

\section{Credibility}

Kredibilitas merupakan suatu perilaku seseorang yang mana mereka percaya jika transaksi dan privasi informasi mereka dilindungi dengan aman sehingga mereka dapat menerima suatu sistem teknologi tersebut. Kredibilitas perusahaan merupakan salah satu faktor utama yang menjadi pertimbangan konsumen dalam memilih perusahaan yang mengeluarkan layanan pembayaran mobile. semakin tinggi kredibilitas perusahaan maka konsumen akan semakin merasa aman dalam bertransaksi sehingga akan bersedia untuk menggunakan kembali layanan tersebut (Alomau \& Ellyawati, 2021)

\section{Usefullness}

Kegunaan adalah dugaan penting dari niat perilaku dalam konteks yang tak terhitung jumlahnya termasuk internet, perdagangan seluler, dan sistem informasi (Jahan, 2018). Konsumen merasa telah mendapatkan manfaat dari penggunaan mobile payment, seperti proses transaksi yang lebih cepat dan produktif serta lebih efisien (Leo \& Danuarta, 2019)

\section{Ease of use}

Kegunaan membantu untuk memenuhi kebutuhan konsumen dalam hal pengelolaan, memimpin tingkat loyalitas yang lebih besar dan sikap positif. Ini mengintegrasikan kemudahan kemampuan belajar pengguna untuk mengelola sistem (Jahan, 2018). Kesulitan dalam pengoperasian mobile payment seringkali menjadi kendala bagi konsumen untuk menggunakannya. 
keputusan konsumen untuk menggunakan kembali layanan mobile banking dipengaruhi oleh pengalaman kemudahan penggunaan (Alomau \& Ellyawati, 2021).

\section{Satisfaction}

Kepuasan merupakan evaluasi umum terhadap suatu produk apakah produk tersebut memenuhi kebutuhan dan keinginan pelanggan atau tidak. la bekerja sebagai syarat utama untuk pembelian di masa depan dan secara langsung mempengaruhi sikap konsumen. Kepuasan pelanggan memegang konsep bahwa memuaskan kebutuhan dan keinginan pelanggan menghasilkan loyalitas pelanggan (Jahan, 2018). Melalui kepuasan, konsumen dapat mengidentifikasi niat mereka untuk terus menggunakan aplikasi lagi dan lagi. Dalam hal ini, niat menggunakan aplikasi pembayaran digital. Jika pengguna puas dengan aplikasi karena berjalan dengan baik dan sangat bermanfaat maka akan meningkatkan niat mereka untuk terus menggunakan aplikasi untuk pembayaran (Juvelin, 2018)

\section{Trust}

Kepercayaan pada dasarnya adalah keadaan psikologis seseorang dalam melakukan suatu aktivitas, dimana kepercayaan ini mengampil peran penting pada saat melakukan pembelian suatu produk, yaitu dengan memberikan dukungan dalam melakukan proses pembelian suatu produk (Liempepas \& Sihombing, 2019). Beberapa penelitian mengungkapkan bahwa kepercayaan merupakan salah satu faktor yang sangat berpengaruh pada penerimaan pelanggan dan penggunaan secara berkelanjutan di dalam berbagai situasi.

\section{E-Service Quality}

E-Service Quality adalah layanan informasi interaktif yang menyediakan mekanisme bagi perusahaan untuk membedakan penawaran layanan mereka dan membangun keunggulan kompetitif. E-Service Quality adalah penilaian konsumen dan kesimpulan dari keunggulan dan kualitas layanan elektronik yang ditawarkan di pasar virtual (Olivia \& Tarumanegara, 2019). Semakin bagus kualitas layanan yang diberikan oleh suatu perusahan maka perilaku penggunaan berulang suatu layanan juga akan semakin meningkat (Safitri \& Aziza, 2021). Menurut Parasuraman dalam (Olivia \& Tarumanegara, 2019) Para ahli telah menjelajahi dan menyelidiki dimensi spesifik kualitas layanan dengan perspektif teoretis yang berbeda. Salah satu kerangka kerja yang paling populer adalah SERVQUAL, yang mengukur konstruk kualitas layanan di antara 5 komponen, yaitu keandalan, jaminan, daya tanggap, bukti fisik, dan empati. Persaingan dalam dompet digital tidak hanya kualitas layanan dan kegunaan yang maksimal dari dompet digital itu sendiri, tetapi untuk memberikan layanan dan memuaskan pelanggan, perusahaan harus mampu menyediakan semua yang dibutuhkan oleh penggunanya 
(Pangestu \& Sukresna, 2021). Menurut Ho dan Lee dalam (Jonathan, 2013), E-Service Quality terdiri 5 dimensi yang terdiri dari Information Quality, Security, Website Functionally, Customer Relationship, dan Responsiveness and Fulfillment.

Information Quality

Information Quality merupakan informasi yang tersedia pada website yang merupakan komponen utama dari yang dirasakan (Jonathan, 2013). Kualitas informasi adalah sejauh mana informasi secara konsisten dapat memenuhi persyaratan dan harapan semua orang yang membutuhkan informasi tersebut untuk melakukan proses mereka (Tina \& Umiyati, 2019). Kualitas informasi sebagai ukuran yang difokuskan pada output yang dihasilkan oleh sistem, dan nilai dari output pengguna (Kumala, 2015). Information Quality cukup diakui sebagai kekuatan penting dan kompetitif di setiap organisasi dan ini akan meningkatkan pilihan penyedia konsumen hanya jika mempertimbangkan fitur perawatan yang dianggap konsumen relevan dengan pilihan penyedia mereka (Popoola, et al., 2014)

\section{Website Functionality}

Dimensi Website Functionality terdiri dari tiga aspek. Navigasi berkaitan dengan betapa mudahnya pengguna mencari informasi pada website. Hal ini dianggap sebagai hal pokok dalam membangun kualitas pelayanan. Tanpa interaksi dengan pelanggan, pelanggan online perlu mencari informasi terhadap produk/jasa yang sedang dicari. Jika pelanggan sering bingung selama proses pencarian, mereka akan berhenti. Desain dan penyajian sebuah website melibatkan mekanisme navigasi yang dapat memengaruhi relevansi dan efisiensi terhadap hasil pencarian. Ini menunjukkan bahwa navigasi memainkan peran yang dominan dalam memberikan layanan yang memuaskan. Aspek kedua, akses website, mengacu pada kemampuan pengguna untuk mengakses sumber daya (termasuk informasi yang berhubungan dengan perjalanan dan fitur layanan) pada website dan hal itu berkaitan dengan kemudahan koneksi dan kecepatan mengunduh. Sangat mungkin bahwa pengguna online akan berhenti dan mengklik situs lain karena terlalu lama bagi mereka untuk mengakses website atau mengunduh sebuah informasi. Jadi, adanya dukungan untuk akses website merupakan salah satu komponen penting yang berkaitan dengan kinerja pelayanan. Bagian ketiga dari dimensi ini menjelaskan fungsi transaksional yang memungkinkan pelanggan untuk merasa bahwa website ini sederhana dan user-friendly untuk menyelesaikan sebuah transaksi. Beberapa komponen, termasuk pemesanan mudah, pembayaran mudah, dan pembatalan mudah, menunjukkan sejauh mana pelanggan yakin bahwa penggunaan website akan melibatkan sedikit usaha atau tidak (Jonathan, 2013). 


\section{Security}

Security (keamanan) berkaitan dengan bagaimana sebuah website terbukti dapat dipercaya bagi pelanggannya. Layanan online yang dilakukan dengan baik dan lancar dapat membangun kepercayaan dan keyakinan kepada pelanggan. Hal ini penting, karena kurangnya kontak interpersonal dengan pelanggan ketika membeli secara online, pelanggan secara khusus perlu memerhatikan keamanan transaksi. Keamanan juga mengacu pada hal privasi pelanggan. Hal ini penting dalam sebuah transaksi online sebab pelanggan mungkin khawatir bahwa informasi pribadi dan transaksi mereka dapat diakses atau digunakan melalui Internet oleh pihak ketiga. Keamanan telah dianggap sebagai dimensi penting dalam hal kualitas layanan dan kepuasan. Kurangnya jaminan keamanan dapat menjadi penghalang utama bagi pelanggan untuk berbelanja secara online. Dapat disimpulkan bahwa keamanan adalah komponen penting dari kualitas ketika pelanggan melakukan transaksi secara online (Jonathan, 2013).

\section{Customer Relationship}

Customer Relationship merupakan komunitas virtual dapat menyatukan informasi dan masyarakat ke dalam sebuah hubungan. Fitur layanan yang disediakan oleh website memberikan kesempatan kepada user (pengguna) untuk berinteraksi dengan pengguna lain. Komunikasi dua arah ini mempemudah pengguna untuk mencari informasi, membuat keputusan membeli, dan memberi feedback atau masukan kepada website. Hubungan ini dapat dikembangkan melalui interaksi dengan komunitas online yang memungkinkan pengguna untuk berpartisipasi, mempelajari, dan berinteraksi online (Jonathan, 2013).

\section{Responsiveness and Fulfillment}

Responsiveness merupakan pengukuran tentang bagaimana sebuah website dapat menjawab pertanyaan atau mengatasi keluhan konsumen pada website dengan cepat dan juga efisien. Fulfillment mengacu pada keberhasilan website dalam menyampaikan produk atau jasanya dan kemampuannya untuk mengoreksi kesalahan yang terjadi selama proses transaksi. Website yang berusaha untuk meminimalkan ketidakpuasan dengan service yang diberikan akan mencapai level yang lebih tinggi dari sebuah evaluasi kualitas yang diberikan oleh para pelanggannya (Jonathan, 2013). 


\section{Brand Image}

Menurut Kottler \& Keller (2016), citra merek adalah nama, istilah, tanda, simbol, desain, atau kombinasi dari hal - hal tersebut, yang dimaksudkan untuk mengidentifikasi barang atau jasa dari seseorang atau sekelompok penjual dan untuk membedakannya dari barang dan jasa pesaing. Citra merek didefinisikan sebagai keseluruhan, gambaran subjektif dari sebuah merek yang dipegang oleh sekelompok orang. Sebagai konstruksi multidimensi, ia mewakili keseluruhan asosiasi simbolik dan utilitarian yang terkait dengan merek. Dalam pengertian ini, ringkasan hasil evaluasi dari abstraksi dan generalisasi struktur multifaset konstruk (Wiedmann, 2007). Citra merek adalah suatu pemahaman konsumen tentang suatu merek tertentu yang mana konsumen akan terus mengingat suatu merek karena keunikan yang dimilikinya sebab merek tersebut berbeda dari merek lainnya. Brand Image yang baik merupakan salah satu aset bagi perusahaan karena Brand Image mempunyai suatu dampak pada setiap persepsi konsumen, dimana masyarakat akan mempunyai kesan positif terhadap perusahaan (Saputra \& Ardani, 2017). David Aaker dan Alexander L. Biel mengemukakan indikator dari Brand Image yaitu sebagai berikut:

Citra Pembuat (Corporate Image)

Sekumpulan asosiasi yang di persepsikan konsumen terhadap perusahaan yang membuat suatu barang atau jasa. Meliputi: popularitas, kredibilitas, jaringan perusahaan dan serta pemakai itu sendiri (Supriyadi \& Indra, 2016). Tujuan dari citra perusahaan adalah untuk memungkinkan pemahaman yang jelas dan akurat tentang perusahaan. Citra perusahaan adalah tentang emosi dan oleh karena itu, citra tentang perusahaan berbeda dari orang ke orang. Yang penting bagi citra adalah untuk memastikan terciptanya niat yang jelas dan baik mengenai korporasi. Ada kemungkinan informasi yang sebagian atau tidak akurat mempengaruhi citra perusahaan secara negatif (Manado, 2018)

Citra Produk (Product Image)

Sekumpulan asosiasi yang di persepsikan konsumen terhadap suatu barang atau jasa. Meliputi: atribut dari produk, manfaat bagi konsumen, serta jaminan (Supriyadi \& Indra, 2016). Citra produk dipandang sebagai elemen penting didalam upaya mempengaruhi keputusan pembelian konsumen. Kualitas yang melekat pada produk merupakan nilai yang akan menjadikan produk memiliki citra yang baik. Sehingga dalam hubungan jangka panjang, nilai dari sebuah produk menjadi sesuatu yang mutlak, karena dengan adanya nilai yang mampu memuaskan inilah yang menjadi landasan konsumen di dalam mengambil keputusan untuk bertransaksi saat ini maupun dimasa mendatang (Saputra \& Listyorini, 2014). 
Citra Pemakai (User Image)

Sekumpulan asosiasi yang dipersepsikan konsumen terhadap pemakai yang menggunakan suatu barang atau jasa. Meliputi: pemakai itu sendiri serta status sosialnya ${ }^{20}$. Citra pemakai merupakan salah satu indikator dari citra merek dan sering menjadi rujukan bagi konsumen dalam pengambilan keputusan pembelian. Pada kondisi yang menguntungkan, pemakai dari sebuah produk mempunyai peran sangat strategis dalam komunikasi pemasaran (Saputra \& Listyorini, 2014).

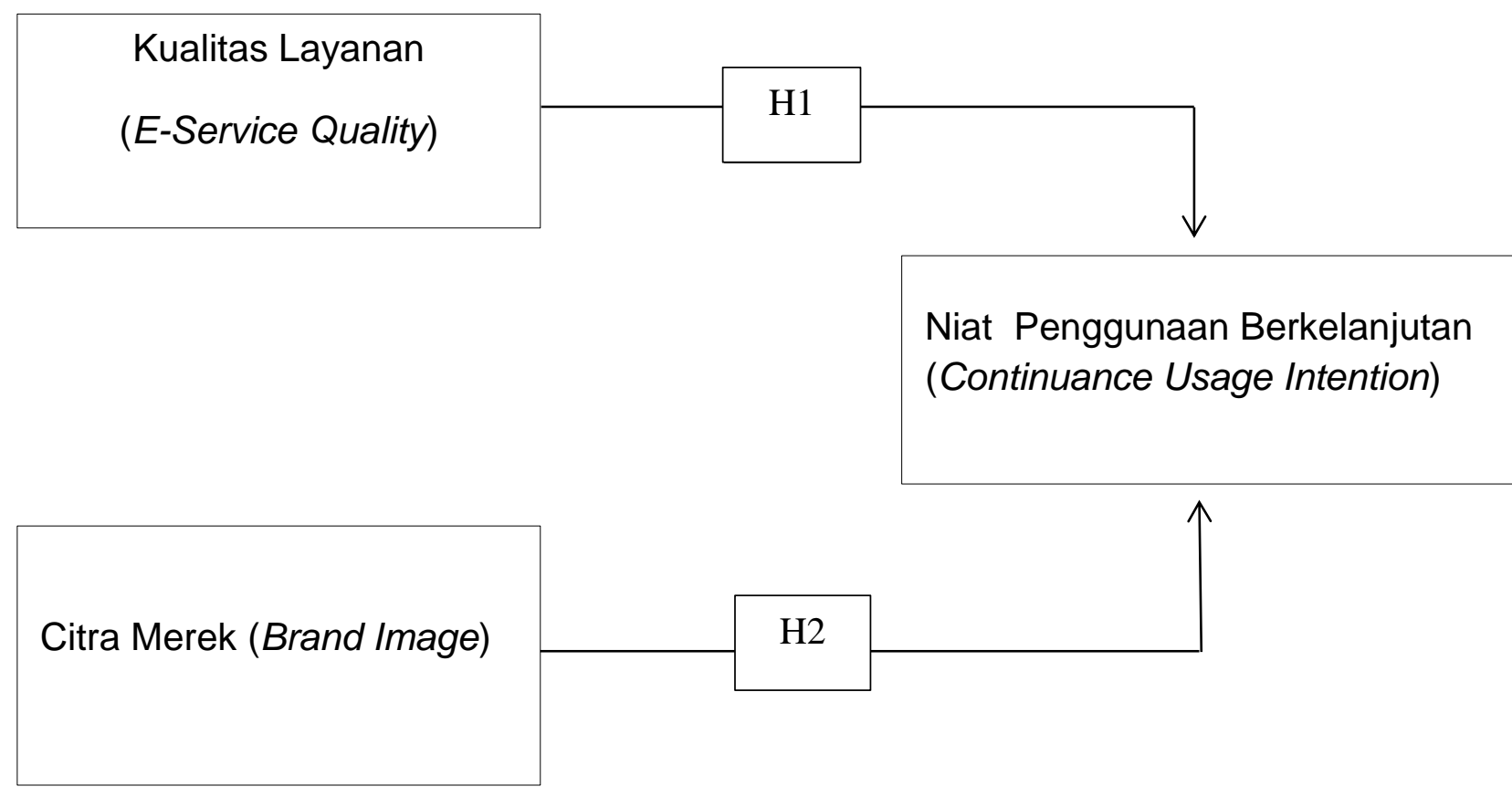

\section{Gambar 3. Kerangka Pemikiran}

H1: Brand Image berpengaruh positif dan signifikan terhadap Continuance Usage Intention pengguna DANA dompet digital.

H2: E-Service Quality berpengaruh positif dan signifikan terhadap Continuance Usage Intention pengguna DANA dompet digital.

\section{METODE PENELITIAN}

Pada penelitian ini, metode sampling yang digunakan adalah purposive sampling yaitu teknik penentuan sampel yang didasarkan pada pertimbangan tertentu yang dianggap 
dapat merepresentasikan suatu populasi. Analisis data dalam penelitian ini menggunakan software SPSS 25 dan smartPLS 3.0. Responden yang diambil sebanyak 100 responden terdiri dari 73 responden wanita dan 27 responden pria. Mayoritas berada pada rentang usia antara $17-25$ tahun dan memiliki pekerjaan sebagai mahasiswa. Adapun kriteria, sebagai berikut:

1) Pengguna smartphone yang pernah menggunakan aplikasi DANA

2) Pengguna smartphone yang sering menggunakan aplikasi DANA

Tabel 1. Indikator Variabel Penelitian

\begin{tabular}{|c|c|c|}
\hline Variabel & Indikator & Sumber \\
\hline $\begin{array}{l}\text { Continuance Usage } \\
\text { Intention }\end{array}$ & $\begin{array}{l}\text { Credibility } \\
\text { Usefullness } \\
\text { Ease of Use } \\
\text { Satisfaction } \\
\text { Trust }\end{array}$ & $\begin{array}{c}\text { Zoel Hutabarat, lan } \\
\text { Nurpatria Suryawan, } \\
\text { Richard Andrew, } \\
\text { Februarga Padua Akwila } \\
\text { (2021) }\end{array}$ \\
\hline E-Service Quality & $\begin{array}{l}\text { Information Quality } \\
\text { Website Functionality } \\
\text { Security } \\
\text { Customer Relation } \\
\text { Responsive \& Fullfilment }\end{array}$ & $\begin{array}{l}\text { Ho, C. I. dan Lee, Y. L. } \\
\text { (2007) }\end{array}$ \\
\hline Brand Image & $\begin{array}{l}\text { Corporate Image } \\
\text { Product Image } \\
\text { User Image }\end{array}$ & $\begin{array}{l}\text { David Aaker dan } \\
\text { Alexander L. Biel (2016) }\end{array}$ \\
\hline
\end{tabular}

\section{HASIL PENELITIAN DAN PEMBAHASAN Uji Reliabilitas dan Validitas}

Pada uji reliabilitas aktual dari penelitian ini, nilai reliabilitas dari setiap variabel bernilai lebih dari 0,60. Di mana nilai Cronbach's Alpha berkisar antara 0,859-0,918 dapat dikatakan bahwa seluruh variabel adalah reliabel.

Tabel 2. Variabel Continuance Usage Intention

Reliability Statistics

\begin{tabular}{r|rr}
\hline $\begin{array}{l}\text { Cronbach's } \\
\text { Alpha }\end{array}$ & $\begin{array}{l}\mathrm{N} \\
\text { Items }\end{array}$ & of \\
\hline, 867 & 10 \\
\hline
\end{tabular}




\section{Tabel 3. Variabel E-Service Quality \\ Reliability Statistics \\ Cronbach's N of

\begin{tabular}{r|r} 
Alpha & Items \\
\hline, 859 & 10 \\
\hline
\end{tabular}

Tabel 4. Variabel Brand Image

\section{Reliability Statistics}

\begin{tabular}{r|lr}
\hline $\begin{array}{l}\text { Cronbach's } \\
\text { Alpha }\end{array}$ & $\begin{array}{l}\mathrm{N} \\
\text { Items }\end{array}$ & of \\
\hline, 918 & 9 \\
\hline
\end{tabular}

Setelah menguji reliabilitas alat ukur selanjutnya adalah pengujian validitas. Pada uji validitas, seluruh variabel dinyatakan valid karena nilai $r$ hitung $>$ dari $r$ tabel. Di mana $r$ tabel $=1,966$ dengan tingkat signifikansi 0,05 .

\section{Uji Normalitas}

\section{Tabel 5. Hasil Uji Normalitas}

One-Sample Kolmogorov-Smirnov Test

\begin{tabular}{llr}
\hline & & \multicolumn{2}{c}{$\begin{array}{c}\text { Unstandardized } \\
\text { Residual }\end{array}$} \\
\hline $\mathrm{N}$ & Mean & 100 \\
\hline Normal Parameters & Std. &, 0000000 \\
\cline { 2 - 3 } & Absolute & 3,08055028 \\
\cline { 2 - 3 } Most Extreme Differences & Positive &, 075 \\
\cline { 2 - 3 } & Negative &, 075 \\
\hline Test Statistic &,- 047 \\
\hline Asymp. Sig. (2-tailed) &, 075 \\
\hline $\begin{array}{l}\text { a. Test distribution is Normal. } \\
\text { b. Calculated from data. } \\
\text { c. Lilliefors Significance Correction. }\end{array}$ &, $179^{c}$ \\
\hline
\end{tabular}


Berdasarkan uji normalitas dengan Kolmogorov-Smirnov Test diperoleh Asymp. Sig sebesar 0.179 lebih besar dari 0.05 maka dapat disimpulkan bahwa data berdistribusi normal.

\section{Uji Multikolinearitas}

Nilai tolerance semua variabel independen lebih besar dari 0.10 yaitu sebesar 0.384 dan nilai VIF semua variabel independen lebih kecil dari 10.00. maka disimpulkan bahwa tidak terjadi multikolonieritas

\section{Coefficients $^{a}$}

\section{Tabel 6. Hasil Uji Multikolinearitas}

\begin{tabular}{|c|c|c|c|c|c|c|c|c|}
\hline Model & & \multicolumn{2}{|c|}{$\begin{array}{l}\text { Unstandardized } \\
\text { Coefficients }\end{array}$} & $\begin{array}{l}\text { Standardized } \\
\text { Coefficients }\end{array}$ & $\mathrm{t}$ & Sig. & \multicolumn{2}{|l|}{$\begin{array}{l}\text { Collinearity } \\
\text { Statistics }\end{array}$} \\
\hline$\overline{1}$ & (Constant) & 6,335 & 1,732 & & 3,658 & ,000 & & \\
\hline & $\begin{array}{l}\text { E-Service } \\
\text { Quality }\end{array}$ & ,416 & ,084 & ,413 & 4,970 & ,000 & 384 & 2,604 \\
\hline & $\begin{array}{l}\text { Brand } \\
\text { Image }\end{array}$ & ,481 & 080 & 499 & 6,002 & ,000 & 384 & 2,604 \\
\hline
\end{tabular}

a. Dependent Variable: Continuance Usage Intention

\section{.Uji Heteroskedastisitas}

Coefficients $^{\mathrm{a}}$

Tabel 7. Hasil Uji Heterosledastisitas

\begin{tabular}{|c|c|c|c|c|c|c|}
\hline \multirow{2}{*}{\multicolumn{2}{|c|}{ Model }} & \multicolumn{2}{|c|}{$\begin{array}{l}\text { Unstandardized } \\
\text { Coefficients }\end{array}$} & \multirow{2}{*}{$\begin{array}{l}\text { Standardize } \\
\text { d } \\
\text { Coefficients } \\
\text { Beta }\end{array}$} & \multirow[b]{2}{*}{$\mathrm{t}$} & \multirow[b]{2}{*}{ Sig. } \\
\hline & & $\mathrm{B}$ & Std. Error & & & \\
\hline \multirow[t]{3}{*}{$\overline{1}$} & (Constant) & 4,167 & 1,054 & & 3,955 & 000 \\
\hline & $\begin{array}{l}\text { E-Service } \\
\text { Quality }\end{array}$ &,- 062 & 051 &,- 195 & $-1,210$ & ,229 \\
\hline & Brand Image & ,009 & ,049 & ,028 & , 176 & ,861 \\
\hline
\end{tabular}

a. Dependent Variable: Abs_Res

Berdasarkan hasil uji heteroskedastisitas dengan metode Glejser diperoleh X1 (E-Service Quality) 0.229 dan X2 (brand image) 0.861 yang lebih besar dari 0.05. sehingga disimpulkan data tidak terjadi masalah heteroskedastisitas. 
Uji Hipotesis

\section{Tabel 8. Hasil Uji Hipotesis}

Path Coefficients

\begin{tabular}{|c|c|c|c|c|c|c|}
\hline \multirow[t]{2}{*}{ 囯 } & T-Values, P-Val... & \multicolumn{2}{|c|}{ Confidence Intervals } & \multicolumn{2}{|c|}{ Confidence Intervals Bias Co... } & 圂 Samples \\
\hline & Original Sampl... & Sample Mean (... & Stand & ard Devia... & T Statistics $(\mid \mathrm{O} / \ldots$ & P Values \\
\hline$X 1->Y$ & 0.408 & 0.426 & & 0.082 & 4.999 & 0.000 \\
\hline$X 2->Y$ & 0.514 & 0.504 & & 0.085 & 6.080 & 0.000 \\
\hline
\end{tabular}

\section{H1: Variabel E-Service Quality berpengaruh positif dan signifikan terhadap variabel Continuance Usage Intention}

Hasil pengujian menunjukan nilai koefisien beta sebesar 0.408 dan t-statistik yaitu sebesar 4.999. dari hasil ini dinyatakan t-statistik signifikan karena $>1.96$ dengan $p$-value $<0.05$ sehingga hipotesis pertama diterima dan terbukti memiliki pengaruh positif.

\section{H2: Variabel Brand Image berpengaruh positif dan signifikan terhadap variabel Continuance Usage Intention}

Hasil pengujian menunjukan nilai koefisien beta sebesar 0.514 dan t-statistik yaitu sebesar 6.080. dari hasil ini dinyatakan t-statistik signifikan karena $>1.96$ dengan $p$-value $<0.05$ sehingga hipotesis kedua diterima dan terbukti memiliki pengaruh positif.

\section{KESIMPULAN DAN SARAN \\ Kesimpulan}

Berdasarkan hasil penelitian yang telah dilakukan melalui tahap pengumpulan data sampai dengan analisis data, maka dapat ditarik kesimpulan yaitu E-Service Quality berpergaruh positif dan signifikan terhadap Continuance Usage Intention. Hal tersebut berarti bahwa penggunan digital wallet sesuai dengan ekspetasi yang diharapkan pengguna dan dapat membantu masalah yang dialaminya. Dan juga pengguna menikmati kelengkapan serta keamanan yang diberikan perusahaan sehingga memicu tingkat kepercayaan pengguna dengan layanan perusahaan yang dapat menunjang aktivitas pembayaran secara berkelanjutan. Brand Image berpengaruh signifikan terhadap Continuance Usage Intention. Hal ini disebabkan digital wallet DANA ini memiliki brand image yang baik yang merupakan faktor paling penting dan dominan bagi konsumen. Dengan brand image yang melekat pada digital wallet DANA mempengaruhi konsumen dalam melakukan keputusan pembelian. 


\section{Saran}

1. Dalam hasil penelitian kedua variabel berpengaruh signifikan sehingga perlu tentunya agar perusahaan digital wallet DANA ini terus menjaga dan memelihara E-Service Quality-nya

2. Selain menambah variabel lain yang memberikan kontribusi terhadap Continuance Usage Intention, diharapkan penelitian selanjutnya menggunakan metode lain yang berbeda untuk membandingkan antara metode penelitian satu dengan yang lainnya

3. Untuk penelitian selanjutnya disarakan agar berfokus pada generasi $Z$ yang sedang berkembang dan turut mendorong kemajuan bisnis digital ini

\section{REFERENSI}

Putra, I. G. W. S. C. PENGARUH PRODUCT USABILITY DAN CASHBACK PROMOTION TERHADAP BRAND LOYALTY LAYANAN DIGITAL WALLET DI INDONESIA. 7, 11-19 (2021).

Wikipedia. Dana (pembayaran). https://id.m.wikipedia.org/wiki/Dana_ (pembayaran) (2021).

Putritama, A. The Mobile Payment Fintech Continuance Usage Intention in Indonesia Niat Penggunaan Berkelanjutan dari Pembayaran Seluler Fintech di Indonesia. 243258 (2019).

Liempepas, I. \& Sihombing, S. O. ANALISIS FAKTOR - FAKTOR YANG MEMPENGARUHI NIAT PENGGUNAAN BERKELANJUTAN: STUDI EMPIRIS PADA MOBILE BANKING BCA. 10, 306-336 (2019).

Jahan, N. Asian Economic and Financial Review PREDICTING CONTINUANCE USAGE INTENTION OF MOBILE PAYMENT: AN EXPERIMENTAL STUDY OF BANGLADESHI Keyword s. 8, 487-498 (2018).

Hutabarat, Z., Suryawan, I. N., Andrew, R. \& Padua, F. Effect Of Performance Expectancy And Social Influence On Continuance Intention In OVO. XXV, 125140.

Alomau, G. P. \& Ellyawati, J. Determinant of Continuance Usage Intention of Mobile Payment Application Using Extended Tam Model. (2021).

Leo, G. \& Danuarta, N. Determinants of Using Go-Pay and its Impact on Net Benefits. 4, (2019).

Juvelin, L. INFLUENCE OF POST-USAGE USEFULNESS, SELF-EFFICACY AND SATISFACTION TOWARDS CONTINUANCE INTENTION OF T-CASH. 1, (2018).

Olivia, W., Studi, P., Manajemen, S. \& Tarumanagara, U. Prediksi E-Service Quality dan Trust Terhadap Kepuasan Pengguna: Word of Mouth Sebagai Variabel Mediasi. I, 
736-747 (2019).

Safitri, B. A. D. \& Azizah, N. Pengaruh E-Service Quality dan Enjoyment Terhadap Repeat Usage E-Wallet GOPAY Melalui Trust Pada Generasi Milenial di Surabaya. 2, 183-202 (2021).

Pangestu, M. A. \& Sukresna, I. M. ( Studi Pada Pengguna Dompet Digital ( e-Wallet ) OVO di Kota Semarang ). 10, 1-11 (2021).

Jonathan, $\mathrm{H}$. TERHADAP CUSTOMER SATISFACTION YANG BERDAMPAK PADA CUSTOMER LOYALTY PT BAYU BUANA TRAVEL TBK. 14, 104-112 (2013).

Tina, Sugiharto, B. \& Umiyati, I. Analysis of System Quality, Information Quality and. J. Account. Sustain. Soc. 1, 48-71 (2019).

Kumala, R. THE IMPACT OF INFORMATION QUALITY AND SYSTEM QUALITY ON USER SATISFACTION IN WEB-BASED INFORMATION SYSTEM (Study on the Employees of Bank Rakyat Indonesia Malang). J. Adm. Bisnis S1 Univ. Brawijaya 19, 85587 (2015).

Popoola, B. A., Chinomona, R. \& Chinomona, E. The influence of information quality, system quality and service quality on student's self-efficacy at institutions of higher learning in South Africa. Mediterr. J. Soc. Sci. 5, 974-984 (2014).

Kotler, P. \& Keller, K. L. Marketing Management. (2016).

Wiedmann, K. Strategie, Marketing und Informationsmanagement.

Saputra, I. \& Ardani, I. Peran Brand Image Dalam Memediasi Pengaruh Green Marketing Terhadap Corporate Reputation. E-Jurnal Manaj. 6, 87-115 (2017).

Supriyadi, Fristin, Y. \& Indra, G. PENGARUH KUALITAS PRODUK DAN BRAND IMAGE TERHADAP KEPUTUSAN PEMBELIAN (Studi pada Mahasiswa Pengguna Produk Sepatu Merek. 3, (2016).

Manado, D. I. Comparison of Retail Corporate Image Between Alfamart and Indomaret in Manado. J. EMBA J. Ris. Ekon. Manajemen, Bisnis dan Akunt. 6, 3158-3167 (2018).

Saputra, D., Waluyo, H. \& Listyorini, S. Effect of Product Quality, Promotion, and Brand Image on Purchase Decision of Nike Sports Shoes (Case Study on S1 Fisip Undip Students). J. IImu Adm. Bisnis 3, 209-220 (2014). 